\title{
Diyabette Kullanılan Bitkisel Desteklerin Etkinliği ve Güvenilirliği
}

\author{
Efficacy and Safety of Herbal Supplements Used in Diabetes
}

\section{Ezgi Bellikci Koyu ${ }^{1}$}

Geliş tarihi/Received: 18.01.2019 • Kabul tarihi/Accepted: 21.04.2019

\section{ÖZET}

Bitkiler uzun yüzylllar boyunca tedavinin en önemli parçası olmuşlardır. On dokuzuncu yüzyılda kimya alanında önemli gelişmelerin olması ve ilaç moleküllerinin keşfi ile bitkilerin tıbbi amaçlı kullanımları giderek azalsa da, son yıllarda doğaya dönüş çabaları içerisinde kullanımlarında yeniden bir artış gözlenmektedir. Özellikle diyabet gibi kronik seyirli hastalıklarda modern tedaviye destek olarak bu ürünlerin kullanımları sıklıkla tercih edilmektedir. Bu ilgiye paralel olarak son yıllarda bitkilerin diyabet tedavisindeki etkisini araştıran klinik çalışmalar da artmaya başlamıştır. Etkinliğin yanı sıra bitkilerin güvenilir kullanımları da son derece önemlidir. Doğru bitkinin kullanımı, kullanılan ürünün bileşimi, kalitesi, hazırlama yöntemi, yan etkileri, ilaç etkileşimleri ve kontraendikasyonları da tedavi sürecini etkileyen ve güvenilir kullanım için göz önünde bulundurulması gereken faktörlerdir. Bu derlemede tarçın (Cinnamomum sp.), çörek otu (Nigella sativa L.), kudret narı (Momordica charantia L.), çemen otu (Trigonella foenum-graecum L.), zencefil (Zingiber officinale Roscoe) ve ısırgan otu (Urtica dioica L.) gibi diyabet tedavisinde sıklıkla tercih edilen bitkilerin etkinliği ve güvenilirliği değerlendirilmiştir.

Anahtar kelimeler: Tamamlayıcı tedavi, tarçın, çörek otu, kudret narı, çemen otu

\begin{abstract}
Plants have been the most important part of the treatment for long centuries. In the nineteenth century, with the developments in chemistry and the discovery of drug molecules, utilization of plants for medicinal purposes gradually decreased. However, in recent years an increasing demand has been observed within the aspect of return to nature. The use of these products is often preferred as a complementary therapy especially in chronic diseases such as diabetes. In parallel with this interest, the number of clinical studies investigating the effects of herbal supplements on the treatment of diabetes has been increasing. Apart from effectiveness, the safe use of plants is crucial. The use of the right plant, composition, and quality of the product, preparation methods, side effects, drug interactions, and contra-indications are also factors which influence the course of the therapy and should be considered. In this review, plants which have been frequently preferred in the treatment of diabetes such as cinnamon (Cinnamomum sp.), black cumin (Nigella sativa L.), bitter melon (Momordica charantia L.), fenugreek (Trigonella foenum-graecum L.), ginger (Zingiber officinale Roscoe) and nettle (Urtica dioica L.) were evaluated in terms of efficacy and safety.
\end{abstract}

Keywords: Complementary therapies, cinnamon, black cumin, bitter melon, fenugreek

1. İletişim/Correspondence: İzmir Kâtip Çelebi Üniversitesi, Sağlık Bilimleri Fakültesi, Beslenme ve Diyetetik Bölümü, İzmir, Türkiye

E-posta: ezgi_bellikci@hotmail.com • ๑ https://orcid.org/0000-0001-5279-2394 


\section{GíRiş}

Tarihsel açıdan değerlendirildiğinde, farmakolojik tedavinin bitkiler ile başladığı ve bitkilerin uzun yüzyıllar boyunca insanoğlunun en başta gelen tedavi araçlarından biri olduğu söylenebilir (1). Farmakognozinin babası olarak kabul edilen Dioscorides'in "De Materia Medica” isimli eseri, antik çağın en önemli tıbbi kitaplarından birisidir. Rönesans’a kadar önemli bir başvuru kaynağı olan bu eserde yer verilen 1000'den fazla reçetenin üçte ikisinin bitkisel kökenli olduğu bilinmektedir (2). On dokuzuncu yüzylldan itibaren kimya alanında önemli gelişmelerin olması ve yapı-etki ilişkisinin anlaşılması ile bilimsel farmakolojinin temelleri atılmıştır. Böylece bitkilerin tıbbi amaçlı kullanımları azalmaya başlamıştır. Bunun yerine bitkilerdeki aktif bileşenlerin izolasyonu ve sentezi sonucu elde edilen moleküller konvansiyonel ilaç üretiminde kullanılmaya başlanmıştır (2).

Bitkilerin ilaç hammaddesi olarak kullanımı dışında, son yıllarda geleneksel yaklaşımla kullanımlarında yeniden bir artış söz konusudur. Özellikle kronik hastalığa sahip bireylerde bitkisel ürünlerin kullanımına yönelik eğilim dikkat çekicidir. Yapılan çalışmalarda diyabetli bireylerin de bu ürünleri sıklıkla tercih ettiği belirlenmiş ve ülkemizde diyabetli bireylerde bitkisel ürün kullanma oranlarının \%27 ile \%36 arasında değiştiği saptanmıştır (3-5).

Diyabetli bireylerin bitkilere karşı artan ilgisinin başlıca nedenleri arasında; hastalığın kronik seyirli oluşu, farmakolojik tedaviye paralel olarak yaşam tarzı değişikliklerini gerektirmesi ve medyada yer alan destekleyici haberler yer almaktadır. Yazılı ve sözlü basında her gün farklı bir bitki "diyabete şifa” olarak tanıtılarak pazarlanmaktadır. Doğal, kimyasal içermez, yan etkilerden uzak gibi ifadeler de bu algıyı ve bitkilerin kontrolsüz kullanımını desteklemektedir. Ürünlerin kontrolsüz kullanımlarına paralel olarak sağlık riskleri de artmaktadır. Bu amaçla, bu derlemede tip 2 diyabette sıklıkla kullanılan bitkilerin etkinlik ve güvenilirlikleri güncel literatür ışığında değerlendirilmiştir.

\section{Tarçın (Cinnamomum sp.)}

Kendine özgü aromasıyla dünyada en sık kullanılan baharatlardan birisi olan tarçın, Lauraceae (Defnegiller) familyasindan Cinnamomum cinsine ait ağaçların kabuklarından elde edilir. Dünyada Cinnamomum cinsine ait yaklaşık 250 türün olduğu bilinmektedir (6). Ancak baharat olarak kullanılan dört temel tür mevcuttur (7). Bunlardan, Cinnamomum zeylanicum (Seylan tarçını) ve Cinnamomum aromaticum (Çin tarçını) en sık kullanılan türlerdir. Seylan tarçınını diğer türlerden morfolojik olarak ayırt etmek mümkündür. Seylan tarçını açık renkli ve yumuşaktır, kolay kırılır. İçi ince tabakalardan oluşmuştur. Diğer tarçınlar ise daha koyu renkli, sert, içi boş ve tek tabakadan oluşmuştur. Zengin aroması nedeniyle Seylan tarçını daha çok tercih edilir. Ancak pahalı olduğu için genellikle Çin tarçını ile karıştırılarak kullanılmaktadır (7). Seylan tarçınının kimyasal bileşimindeki en önemli bileşenler uçucu yağındaki trans-sinnamaldehit, öjenol ve linalooldür. Çin tarçının karakteristikbileşenleriise sinnamaldehit, sinnamik asit, sinnamil alkol ve kumarindir (8).

Yapılan in-vivo çalışmalarda, sinnamaldehitin ve tarçının doza bağlı olarak glisemik kontrole yardımcı olabileceği gösterilmiştir $(9,10)$. Öne sürülen etki mekanizmaları arasında; insülin sinyal yolağının etkinliğinin artırılmasıyla insülin aracılı glukoz kullanımının artmasıveinsülin benzeri etkigöstermesi yer almaktadır (11). In-vivo çalışmalardaki olumlu sonuçlar, ilgiyi klinik çalışmalara yoğunlaştırmış ve tarçının diyabet üzerine etkisini araştıran küçük çaplı pek çok klinik çalışma yapılmıştır. Bu çalışmaların değerlendirildiği 2012 yllı Cochrane derlemesinde, tarçının tip 1 ve tip 2 diyabet üzerine etkisini araştıran toplam 10 klinik çalışma ( $n=577)$ incelenmiştir (12). Çalışmalarda çoğunlukla Çin tarçınının ortalama 2 g/gün dozda, 4-16 hafta süre ile verildiği saptanmıştır. Meta-analiz sonucunda açlık kan glukozundaki değişim için kanıtların yetersiz olduğu bildirilmiştir. Hemoglobin A1c (HbA1c), serum insülin ya da postprandiyal glukoz düzeylerinde ise 
tarçın tüketenlerde plasebo alanlara göre istatistiksel olarak anlamlı bir değişimin olmadığı saptanmıştır (12). Cochrane derlemesinden 4 yll sonra, sadece tip 2 diyabetik bireylerin incelendiği çalışmaları ele alan başka bir derleme çalışma yapılmıştır (13). Toplam 11 çalışmanın $(n=694)$ dahil edildiği bu derlemenin dört çalışması Cochrane derlemesi ile ortak olup, diğerleri Cochrane derlemesinden sonra yayınlanan çalışmalardan oluşmuştur. Dahil edilen çalışmalarda, tarçının 4-16 hafta süre ile 120 mg ile 6 g arasında değişen dozlarda kullanıldı̆̆ belirlenmiştir. İncelenen 11 çalışmanın tamamında, açlık kan glukoz düzeylerinde belirli derecelerde düşüş olduğu ve dozun 3- 6 g gibi daha yüksek miktarda kullanıldığı çalışmalarda açlık kan glukoz düzeylerinde saptanan azalmanın daha fazla olduğu belirlenmiştir. HbA1c düzeylerinde ise ortalama \%0.49 oranında azalma olduğu saptanmıştır. Aynı derlemede, standart tedaviye tarçın eklenmesi ile Amerikan Diyabet Derneği'nin (American Diabetes Association [ADA]) tedavi hedeflerine ulaşıp ulaşılamadığı incelendiğinde, sadece dört çalışmada tarçın kullanımı ile diyabetin tedavi hedeflerine ulaşllabildiği saptanmıştır. Bu nedenle yazarlar, glisemik parametrelerdeki değişimlerin istatistiksel olarak anlamlı olmasına rağmen klinik olarak anlamlı düzeyde olmadığını bildirmiş, standart tedavi ve yaşam tarzı değişikliklerine ek olarak kullanılan tarçının sınırlı düzeyde etkisinin olabileceğini belirtmişlerdir (13).

Yapılan çalışmaların çoğunluğunun Çin tarçını ile yürütülmesi etkinlik ile beraber güvenilirlik problemini de ortaya çıkarmaktadır. Çin tarçını, yüksek dozlarda hepatotoksik olduğu bilinen kumarin maruziyetine neden olmaktadır $(14,15)$. Almanya Federal Risk Değerlendirme Enstitüsü (German Federal Institute for Risk Assessmentbfr) diyabet için satılan ürünlerin bileşimindeki Çin tarçın tozlarının yaklaşık 2.1-4.4 g/kg kumarin içerdiğini bildirmiştir (15). Başka bir çalışmada, 60 farklı tarçın tozu incelenmiş ve kumarin içeriğinin 2.7-7.0 g/kg olduğu saptanmıştır (16). Bu çalışmalar baz alındığında bir çay kaşığı toz tarçının 5.3-18 mg kumarin içerdiği görülmektedir. Bu değerler, Avrupa Gıda Güvenliği Otoritesi'nin (European Food Safety Authority [EFSA]) kumarin için önerdiği günlük tolere edilebilen miktarın (0-0.1 $\mathrm{mg} / \mathrm{kg})$ üzerinde alıma neden olabilmektedir (14). Öte yandan diğer tarçın çeşidi olan Seylan tarçınının kumarin içeriği oldukça düşüktür. Ancak pahalı olduğu için genellikle piyasada Çin tarçını ile karıştırılarak satılmaktadır. Seylan tarçının diyabet üzerine etkisini araştıran preklinik veriler umut vaat edici olsa da (17), Seylan tarçını ile tamamlanmış klinik araştırma şimdilik bulunmamaktadır. Özetle üzerinde daha çok çalışma yapılan Çin tarçının glisemik profile etkisinin oldukça sınırlı olduğu ve hepatotoksik bileşen olan kumarin açısından zengin olması nedeniyle kullanımının önerilmediği söylenebilir. Kumarin içeriği düşük olan Seylan tarçınına ilişkin olarak ise klinik çalışma bulunmadığından yorum yapmak için erkendir.

\section{Çörek otu (Nigella sativa L.)}

Güney Avrupa, Kuzey Afrika, Batı Asya ve Anadolu'da doğal olarak yetişen bir bitki olan çörek otunun tohumları ve tohumlarından elde edilen yağı uzun yıllardan beri ülkemizde halk arasında birçok rahatsızlığa karşı kullanılmaktadır (18). Çörek otu tohumlarının 100'den fazla kimyasal bileşik içerdiği bilinmekle birlikte timokinon, timohidrokinon, ditimokinon ve timol en önemli aktif bileşenlerindendir (18). Diyabete ilişkin olarak yapılmış in-vivo çalışmalarda çörek otunun diyabet üzerine olumlu etkileri olduğu görülmektedir $(19,20)$. Çörek otunun diyabet üzerine olan potansiyel etkileri birçok farklı mekanizma ile ilişkilendirilmektedir. $\mathrm{Bu}$ mekanizmalar arasında karaciğerde insülin duyarlılığının artması, glukoneogenezin baskılanması, kaslarda glukoz kullanımınin artması, pankreasta insülin salınımının ve $\beta$ hücre proliferasyonun artması ve gastrointestinal sistemden glukoz emiliminin azalması yer almaktadır (21).

In-vitro ve in-vivo çalışmalar umut vaat edici olsa da çalışmaların kliniğe taşınması henüz çok yenidir. Kaatabi et al. (22) tarafindan yürütülmüş bir çalışmada, tip 2 diyabet hastalarına standart oral 
antidiyabetik tedavisine ek olarak bir yll süreyle $2 \mathrm{~g}$ çörek otu tohumu ya da plasebo verilmiştir. Çalışmanın sonunda açlık kan glukozu ve HbA1c düzeyleri açısından çörek otu alan grupta kontrol grubuna göre istatistiksel olarak anlamlı azalmalar olduğu belirlenmiştir. Ayrıca, çörek otu alan grupta çalışma sonunda başlangıca göre insülin direncinin daha düşük, $\beta$-hücre aktivitesinin ise daha yüksek olduğu saptanmıştır. Bamosa et al. (23), farklı dozlarda çörek otu tohumunun glisemik kontrole etkisini incelemişlerdir. Toplam 12 hafta süreyle 1, 2

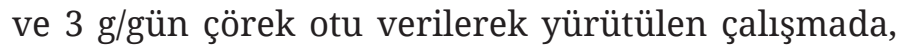
optimum dozun $2 \mathrm{~g}$ gün olduğu belirlenmiştir. Günlük 2 g doz ile 12 hafta sonunda açlık kan glukoz düzeylerinde ortalama $56 \mathrm{mg} / \mathrm{dL}, \mathrm{HbA1c}$ düzeylerinde ise ortalama \%1.52 oranında azalma sağlandığı gösterilmiştir. Ayrıca, insülin direnci ve $\beta$ hücre aktivesinde de bir önceki çalışmaya benzer şekilde olumlu değişimler olduğu saptanmıştır. Çörek otunun 1 g/gün kullanılmasının da glisemik parametrelerde olumlu etkiler gösterdiği ancak istatistiksel olarak anlamlı olmadığı bildirilmiştir. Çörek otunun 3 g/gün verilmesinin ise $2 \mathrm{~g} / \mathrm{gün}$ verilmesine kıyasla ilave bir yarar sağlamadığı bildirilmiştir (23).

Tohum yağının topikal kullanımı sonrası kontakt dermatit geliştiği gözlenen vaka raporları dışında çörek otu tohumunun bilinen yan etkisinin bulunmadığı ve tohum ekstrelerinin toksisitelerinin düşük olduğu bilinmektedir (18,24). Buna karşın, ülkemizden bildirilen bir vaka raporunda 6 gün süreyle çörek otu tableti (2-2.5 g/gün) kullanan 62 yaşında diyabetik bir kadın hastada akut böbrek yetmezliği geliştiği saptanmış ve bu durum çörek otu ile ilişkilendirilmiştir (25). Çörek otu ile yapılan klinik çalışmaların birçoğunda düşük bir dozda ve kısa süreli olarak kullanıldığı halde böyle bir durumun gelişmesi, benzer başka bir raporun olmayışı da göz önüne alındığında, sorunun çörek otunun kendisinden çok, kullanılan ürünün kalitesi ve bileşimi ile ilişkili olabileceğini düşündürmektedir (26). Ürüne bulaşmış toksik bir maddenin böbrek fonksiyonlarında bozulmaya yol açmış olması olasıdır. Bu olası tablo da piyasada satılan bitkisel ürünlerdeki kalite sorununu ortaya çıkarmaktadır. Bitkisel ürünlere, ürünün etkisini artırmak amaçlı kimyasalların eklenebildiği ayrıca bitkisel ürünlerin birçoğunda ağır metal, pestisit, insektisid gibi kontaminasyonların olabileceği rapor edilmiştir (27). Bu nedenle, kullanılacak bitkinin güvenilir olması kadar ürünün de güvenilir olmasına çok dikkat edilmelidir.

\section{Kudret Narı (Momordica charantia L.)}

Cucurbitaceae (Kabakgiller) familyasından bir bitki olan kudret narının meyveleri dünyanın çeşitli bölgelerinde sebze olarak kullanılmakta ve yemeği yapılarak tüketilmektedir (28). Ülkemizde ise doğal olarak yetişmemekte, bahçelerde süs bitkisi olarak yetiştirilmektedir (29). Kudret narının meyvesi ve tohumlarının, Güneydoğu Asya'da diyabete karşı kullanılan bitkiler arasında popüler olduğu bilinmektedir (28). Yapılan çalışmalarda, kudret narının antioksidan etki gösterdiği, glukoz ve lipit metabolizmasının regülasyonunda etkili olduğu saptanmıştır (28,30,31). Farklı ekstreleri ile yürütülen çalışmalarda, kan glukoz düzeyi yüksek olan ratlarda hipoglisemik etki gösterdiği belirlenmiştir (30-32). Meyvenin bileşimindeki triterpenik bileşiklerin (karantin, visin vb.) ve polipeptit-p gibi insülin benzeri peptidlerin glisemik kontrolden sorumlu temel bileşikler olduğu düşünülmektedir (29,33,34). Kudret narının hipoglisemik aktivitesine ilişkin öne sürülen mekanizmalar arasında, iskelet kaslarında glukoz kullanımının uyarılması, bağırsaklardan glukoz emiliminin azalması, adiposit farklılaşmasının baskılanması, glukoneogenezin baskllanması, $\beta$-hücrelerinin ve fonksiyonlarının korunması yer almaktadır (34).

Kudret narı ile yürütülmüş in-vivo çalışmalardaki olumlu sonuçlara karşın klinik çalışmaların sonuçları çelişkilidir. Küçük örneklemli bazı klinik çalışmalar kudret narının hipoglisemik etkinliğini desteklese de bu çalışmaların çoğunluğu randomize kontrollü olarak planlanmamıştır $(35,36)$. Randomize kontrollü olarak yürütülen dört çalışmanın $(n=479)$ incelendiği 2012 yll Cochrane derlemesinde ise tip 2 diyabetin 
kontrolünde plaseboya göre anlamlı bir etkisinin olmadığı sonucuna varılmıştır (37).

Kudret narının uterus kasılmalarını artırdığından düşüğe sebep olabileceği, bu nedenle gebeler tarafından kullanılmaması gerektiği bildirilmiştir. Ayrıca çocuklar, emziren anneler, infertilite tedavisi gören bireyler ve kabakgiller familyasındaki bitkilere/besinlere alerjisi olanlar tarafindan da kullanılmamalıdır. Glukoz-6-fosfat dehidrogenaz enzim eksikliği olanlarda favizm türü sendrom riskinden dolayı kullanımı önerilmemektedir $(29,38)$. Bitkinin uzun süreli kullanımı da ( $>4$ hafta) tavsiye edilmemektedir (29). Bitkinin tadı acı olduğu için, liyofilize edilmiş toz halinde kapsül olarak kullanımı tercih edilebilmektedir $\mathrm{Bu}$ durumun, yüksek doz tüketime ve toksisiteye neden olmamasina dikkat edilmelidir (38).

\section{Çemen otu (Trigonella foenum-graecum L.)}

Fabaceae (Baklagiller) familyasından bir bitki olan çemen otu, Türkiye'de hemen her bölgede yetişen ve kültürü yapılan bir bitkidir. Bitkinin kullanılan kısmı yaprakları ve tohumlarıdır (29). Baharat olarak mutfaklarda sıklıkla kullanılan çemen otu, ülkemizde pastırmanın üzerine sürülen çemenin karışımında yer almaktadır (29,39). Tohumda bulunan ve çözünür posa olan galaktomannan, ekmeğin fizikokimyasal özelliklerini ve besin değerini artırdığı için Afrika mutfağında ekmek yapımında kullanılmaktadır (39). Galaktomannan aynı zamanda gastrointestinal kanaldan karbonhidrat geçişini ve emilimini yavaşlatmaktadır. Galaktomannan dışında çemen otu tohumunun bileşimindeki diosgenin ve 4-hidroksiizolösinin çeşitli hücre kültürlerinde antidiyabetik etki gösterdiği saptanmıştır (39). Losso et al. (40), tip 2 diyabetik bireylerde $\% 5$ oranında çemen tohumu içeren ekmek tüketiminin buğday ekmeği tüketimine göre postprandiyal insülin yanıtını daha az artırdığını saptamıştır. Çemen otu tohumun diyabet üzerine etkisinin araştırıldığ bir meta-analizde, prediyabeti ya da diyabeti olan bireylerle yapılmış 10 randomize kontrollü klinik çalışma $(n=1173)$ değerlendirilmiştir. Meta-analizde yer alan çalışmalarda 1 g ile100 g (medyan 6 g) arasında dozlar kullanılmış ve 1 hafta-3 yıl arasında değişen sürelerde (medyan süre 60 gün) müdahale yapılmıştır. Meta-analizin sonucunda açlık kan glukoz düzeylerinde (ortalama fark: $-15 \mathrm{mg} / \mathrm{dL}$ ) ve HbA1c düzeylerinde (ortalama fark: -1.16) anlamlı azalma olduğu saptanmıştır. Meta-analizi gerçekleştiren araştırmacılar bu bulguların, metodolojik kalitesi daha iyi olan çalışmalarla desteklenmesi gerektiğini vurgulamışlardır (41).

Çemen otunun glisemik kontrol üzerine olan etkisini açıklayan mekanizmalar arasında gastrik boşalmayı geciktirmesi, glukoz ve yağ emilimini seçici olarak azaltması, glukoz transportunun inhibisyonu, $\beta$ hücrelerinden insülin salınımının uyarılması, insülin duyarlılığının artması, oksidatif stresin azaltılması ve glukagon benzeri peptid-1'in modülasyonu yer almaktadir (41).

Çemen otu yüksek posa içeriğinden dolayı ilaçların absorbsiyonunu azaltabilmektedir. Bu nedenle, ilaç kullanan bireylerde çemen otunun kullanımına dikkat edilmelidir. Ayrıca tohumlarının uterusu uyarıcı etkisi sebebiyle gebelik süresince kullanımı önerilmemektedir. Diğer yan etkileri arasında, diyare, gaz, gibi gastrointestinal sistem şikayetleri ve alerjik reaksiyonlar yer almaktadir (29).

\section{Zencefil (Zingiber officinale Roscoe)}

Güneydoğu Asya'da doğal olarak yetişen zencefilin rizomları, kendine özgü kokusu ve taşıt tutmasına bağlı bulantı ve kusmaya karşı olan etkisiyle popüler olan bir bitkidir. Taze zencefilin keskin tadından sorumlu olan bileşik grubu gingerollerdir. Gingeroller dışında bileşimindeki biyoaktif bileşenler arasında zingiberen ve şogaoller yer almaktadır (42). Yapılan preklinik çalışmalarda, zencefilin a-amilaz, a-glukosidaz enzim inhibisyonunu, glukoz taşıyıcı protein-4 (GLUT-4) translokasyonunu ve insülin duyarlılığını artırmada etkili olduğu bildirilmiştir (43). Mevcut klinik çalışmalar henüz sinırlı olmakla birlikte preklinik bulguları destekliyor gibi görünmektedir. Tip 2 diyabetik 64 hasta ile yürütülen 
randomize, çift kör plasebo kontrollü bir çalışmada iki ay süreyle, $2 \mathrm{~g} /$ gün zencefil tüketiminin plaseboya göre insülin duyarlılığının artması ile ilişkili olduğu bulunmuştur. Açlık kan glukozu ve HbA1c düzeyleri üzerine ise etki görülmemiştir (44). Diyabetik bireylerin dahil edildiği $(n=88)$ bir başka çalışmada ise 8 hafta süreyle $3 \mathrm{~g} / g u ̈ n$ zencefil tüketenlerde açlık kan glukoz düzeylerinin \%10.5 oranında azaldığı; buna karşın plasebo alanlarda \%21 oranında arttığı belirlenmiştir. Aynı çalışmada, zencefil tüketen grupta HbA1c düzeylerinin plasebo grubuna göre anlamlı olarak azaldığı da saptanmıştır (45). Arablou et al. (46), diyabetik bireylerde günlük $1600 \mathrm{mg}$ zencefil kullanımının 12 hafta sonunda glisemik parametreler üzerine olumlu etkisinin olduğunu saptamışlardır.

Zencefil kullanımının yan etkilerine ilişkin kayıtlar arasında duyarlı hastalarda gelişen parmak ucu kontakt dermatiti yer almaktadır. Safra taşı olan kişiler, antikoagülan ilaç kullanan veya kan pıhtılaşma sorunu olan bireylerde, hekim gözetiminde kullanılmalıdır. Altı gramdan fazla zencefilin, midede irritasyona sebep olabileceği bildirilmiştir (18).

\section{Isırgan Otu (Urtica dioica L.)}

Ülkemizin hemen her yerinde yaygın olarak yetişen ısırgan otu, halk arasında çeşitli hastalıklara karşı yaygın olarak kullanılan bir bitkidir (18). Son yıllarda medyanın da etkisiyle kanser hastaları arasında popüler olan bitkinin hem toprak üstü hem de toprak altı kısımlarının etnobotanik çalışmalarda diyabete karşı da sıklıkla kullanıldığı saptanmıştır (47). Halk arasındaki bu yaygın kullanıma karşın, ısırgan otunun antidiyabetik aktivitesinin araştırıldığı klinik çalışmalar çok sınırlıdır $(48,49)$. Kianbakht et al. (49) tarafından yürütülen tek kör, plasebo kontrollü bir çalışmada, tip 2 diyabetli bireylere standart tedaviye ek olarak günde üç kez 500 mg ısırgan otu yaprağının etanolikekstresi $(n=46)$ ya da plasebo $(n=46)$ verilmiştir. Toplam 12 hafta süren çalışmanın sonunda, açlık kan glukoz, postprandiyal glukoz ve HbA1c seviyelerinde plasebo grubuna göre istatistiksel olarak anlamlı azalmalar olduğu belirlenmiştir (48). Nazami et al. (49) ise 45 tip 2 diyabetli bireye 8 hafta süreyle ısırgan otunun hidroalkolik ekstresinin $100 \mathrm{mg} / \mathrm{kg} /$ gün dozda verilmesinin insülin direncinde anlamlı bir değişiklik yaratmadığını saptamışlardır (49). Çalışmalarda ısırgan otu alan gruplarda yan etki görülmediği bildirilmekle birlikte; monograflarda ısırgan otunun bulantl, kusma ve ishal gibi gastrointestinal sistem şikayetlerine ve alerjik reaksiyonlara neden olabileceği bildirilmiştir (18).

Isırgan otunun diyabet ile ilişkisine ilişkin çalışmaların sayıca çok az olması, bu konuda yapılacak iyi planlanmış klinik çalışma ihtiyacını ortaya koymaktadır. Ayrıca dikkate değer bir nokta olarak, çalışmalarda kullanılan ekstreler halkın kullandığı hazırlama yönteminden farklıdır. $\mathrm{Bu}$ nedenle, çalışmalarda kullanılan ekstreden sağlanan biyoaktif bileşenlerin, besini tüketirken ya da çayını içerken alınması olası olmayabilir. Bu nedenle bitkilerin etkinliklerine ilişkin çalışmaları değerlendirirken bitkinin kullanıldığı formun da göz önüne alınarak değerlendirilme yapılması ya da öneri verilmesi önemlidir.

\section{SONUÇ VE ÖNERILER}

Bitkilerin birçok hastalıkta olduğu gibi diyabet tedavisinde de elbette önemli rolü ve etkisi vardır. Günümüzde çok sık kullanılan bir oral antidiyabetik olan metforminin de kökeni bir bitkiye (Galega officinalis) dayanmaktadır. Ancak bu bitkide bulunan guanidinler etkili olduğu kadar toksik de olduğu için doğrudan tedavide kullanılamamıştır. Klinik kullanım için bu bileşikten yola çıkarak etkili ancak toksik olmayan yeni biguanidinler sentezlenmiştir. $\mathrm{Bu}$ örnek aslında bitkilerle ilişkili durumu oldukça güzel açıklamaktadır. Bitkiler yararlı olabilir ancak aynı zamanda son derece zararlı da olabilir.

Bu makalede bahsedilen bitkilerin bir kısmı ilerleyen zamanlarda diyetin bir bileşeni olarak ya da bir ilaç molekülü olarak diyabetin tedavisinde rol alabilir. Ancak şu andaki veriler bu bitkilerin hiçbirini önermek için yeterli düzeyde değildir. İncelenen bitkilere ait klinik çalışmaların sayıları henüz çok azdır. İlerleyen süreçte iyi planlanmış randomize 
kontrollü klinik çalışmalarla etkinliğin yanı sıra doz, kullanım şekli, yan etkiler ve uzun süreli kullanıma ilişkin veriler de geldiğinde diyabet tedavisindeki rolleri açığa kavuşacaktır.

Çıkar çatışması - Conflict of interest: Yazarlar çıkar çatışması olmadığını beyan ederler. - The authors declare that they have no conflict of interest.

\section{KAYNAKLAR}

1. Schulz V, Hänsel R, Blumenthal M, Tyler VE. Rational phytotherapy: A reference guide for physicians and pharmacists. 5th ed. Germany, Springer Science \& Business Media; 2004.

2. Sewell RD, Rafieian-Kopaei M. The history and ups and downs of herbal medicines usage. J Herbmed Pharmacol. 2014;3(1):1-3.

3. Ceylan S, Azal O, Taşlıpınar A, Türker T, Açıkel CH, Güleç M. Complementary and alternative medicine use among Turkish diabetes patients. Complement Ther Med. 2009;17(2):78-83.

4. Küçükgüçlü Ö, Kizilci S, Mert H, Uğur Ö, Besen DB, Ünsal E. Complementary and alternative medicine use among people with diabetes in Turkey. West J Nurs Res. 2012;34(7):902-16.

5. Ilhan M, Demir B, Yüksel S, Çataklı SA, Yıldız RS, Karaman $\mathrm{O}$, et al. The use of complementary medicine in patients with diabetes. North Clin Istanb. 2016;3(1):34-8.

6. Rao PV, Gan SH. Cinnamon: A multifaceted medicinal plant. Evid Based Complement Alternat Med. 2014;642942.

7. Kawatra P, Rajagopalan R. Cinnamon: Mystic powers of a minute ingredient. Pharmacognosy Res. 2015;7(Suppl1):1-6.

8. Gruenwald J, Freder J, Armbruester N. Cinnamon and health. Crit Rev Food Sci Nutr. 2010;50(9):822-34.

9. Kim SH, Hyun SH, Choung SY. Anti-diabetic effect of cinnamon extract on blood glucose in $\mathrm{db} / \mathrm{db}$ mice. J Ethnopharmacol. 2006;104(1-2):119-23.

10. Subash Babu P, Prabuseenivasan S, Ignacimuthu S. Cinnamaldehyde--a potential antidiabetic agent. Phytomedicine. 2007;14(1):15-22.

11. Ulbricht C, Seamon E, Windsor RC, Armbruester N, Bryan JK, Costa D, et al. An evidence-based systematic review of cinnamon (Cinnamomum spp.) by the natural standard research collaboration. J Diet Suppl. 2011;8(4):378-454.

12. Leach MJ, Kumar S. Cinnamon for diabetes mellitus. Cochrane Database Syst Rev. 2012(9):CD007170.
13. Costello RB, Dwyer JT, Saldanha L, Bailey RL, Merkel J, Wambogo E. Do cinnamon supplements have a role in glycemic control in type 2 diabetes? A narrative review. J Acad Nutr Diet. 2016;116(11):1794-802.

14. European Food Safety Association. Coumarin in flavourings and other food ingredients with flavouring properties. EFSA J 2008;793:1-15.

15. BfR. High daily intakes of cinnamon: Health risk cannot be ruled out. Health Assessment No. 044/2006.

16. Blahová J, Svobodová Z. Assessment of coumarin levels in ground cinnamon available in the $\mathrm{Czech}$ retail market. Scientific World Journal. 2012;2012:263851.

17. Ranasinghe $\mathrm{P}$, Jayawardana R, Galappaththy $\mathrm{P}$, Constantine GR, de Vas Gunawardana N, Katulanda P. Efficacy and safety of 'true' cinnamon (Cinnamomum zeylanicum) as a pharmaceutical agent in diabetes: A systematic review and meta-analysis. Diabet Med. 2012;29(12):1480-92.

18. Demirezer Ö, Ersöz T, Saraçoğlu İ, Şener B. Tedavide kullanılan bitkiler "FFD Monografları". 2. baskı. Ankara, Akademisyen Kitabevi; 2011.

19. Abdelmeguid NE, Fakhoury R, Kamal SM, Al Wafai RJ. Effects of Nigella sativa and thymoquinone on biochemical and subcellular changes in pancreatic betacells of streptozotocin-induced diabetic rats. J Diabetes. 2010;2(4):256-66.

20. Meddah B, Ducroc R, El Abbes Faouzi M, Eto B, Mahraoui L, Benhaddou-Andaloussi A, et al. Nigella sativa inhibits intestinal glucose absorption and improves glucose tolerance in rats. J Ethnopharmacol. 2009;121(3):419-24.

21. Razavi BM, Hosseinzadeh H. A review of the effects of Nigella sativa L. and its constituent, thymoquinone, in metabolic syndrome. J Endocrinol Invest. 2014;37(11):1031-40.

22. Kaatabi H, Bamosa AO, Badar A, Al-Elq A, Abou-Hozaifa $B$, Lebda F, et al. Nigella sativa improves glycemic control and ameliorates oxidative stress in patients with type 2 diabetes mellitus: Placebo controlled participant blinded clinical trial. PLoS One. 2015;10(2):e0113486.

23. Bamosa AO, Kaatabi H, Lebdaa FM, Elq AM, Al-Sultanb A. Effect of Nigella sativa seeds on the glycemic control of patients with type 2 diabetes mellitus. Indian J Physiol Pharmacol. 2010;54(4):344-54.

24. Zedlitz S, Kaufmann R, Boehncke WH. Allergic contact dermatitis from black cumin (Nigella sativa) oilcontaining ointment. Contact Dermatitis. 2002;46(3):188.

25. Arslan E, Sayın S, Demirbaş Ş, Çakar M, Somak NG, Yeşilkaya Ş, et al. A case study report of acute renal failure associated with Nigella sativa in a diabetic patient. J Integr Med. 2013;11(1):64-6.

26. Bamosa A. Nigella sativa is a safe herbal product. J Integr Med. 2014;12(1):66. 
27. Posadzki P, Watson L, Ernst E. Contamination and adulteration of herbal medicinal products (HMPs): An overview of systematic reviews. Eur J Clin Pharmacol. 2013;69(3):295-307.

28. Chaturvedi P. Antidiabetic potentials of Momordica charantia: Multiple mechanisms behind the effects. J Med Food. 2012;15(2):101-7.

29. Demirezer Ö, Ersöz T, Saraçoğlu İ, Şener B, Köroğlu A, Yalçın F. FFD monografları bitkiler ve etkileri. 3. Basım. Ankara, Akademisyen Kitabevi; 2017.

30. Nkambo W, Anyama NG, Onegi B. In vivo hypoglycemic effect of methanolic fruit extract of Momordica charantia L. Afr Health Sci. 2013;13(4):933-9.

31. Singh N, Gupta M, Sirohi P, Varsha. Effects of alcoholic extract of Momordica charantia (Linn.) whole fruit powder on the pancreatic islets of alloxan diabetic albino rats. J Environ Biol. 2008;29(1):101-6.

32. Fernandes NP, Lagishetty CV, Panda VS, Naik SR. An experimental evaluation of the antidiabetic and antilipidemic properties of a standardized Momordica charantia fruit extract. BMC Complement Altern Med. 2007;7:29.

33. Krawinkel MB, Keding GB. Bitter gourd (Momordica charantia): A dietary approach to hyperglycemia. Nutr Rev. 2006;64(7 Pt 1):331-7.

34. Joseph B, Jini D. Antidiabetic effects of Momordica charantia (bitter melon) and its medicinal potency. Asian Pac J Trop Dis. 2013;3(2):93-102.

35. Tsai CH, Chen EC, Tsay HS, Huang CJ. Wild bitter gourd improves metabolic syndrome: A preliminary dietary supplementation trial. Nutr J. 2012;11:4.

36. Hasan I, KhatoonS. Effect of Momordica charantia (bitter gourd) tablets in diabetes mellitus: Type 1 and type 2. Prime Res Med (prom). 2012;2(2):72-4.

37. Ooi CP, Yassin Z, Hamid TA. Momordica charantia for type 2 diabetes mellitus. The Cochrane Database Syst Rev. 2012(8):CD007845.

38. Geil P, Shane-McWhorter L. Dietary supplements in the management of diabetes: Potential risks and benefits. Am Diet Assoc. 2008;108(4):59-65.

39. Nagulapalli Venkata KC, Swaroop A, Bagchi D, Bishayee A. A small plant with big benefits: Fenugreek (Trigonella foenum-graecum Linn.) for disease prevention and health promotion. Mol Nutr Food Res. 2017;61(6)1600950

40. Losso JN, Holliday DL, Finley JW, Martin RJ, Rood JC,
Yu Y, et al. Fenugreek bread: A treatment for diabetes mellitus. J Med Food. 2009;12(5):1046-9.

41. Gong J, Fang K, Dong H, Wang D, Hu M, Lu F. Effect of fenugreek on hyperglycaemia and hyperlipidemia in diabetes and prediabetes: A meta-analysis. J Ethnopharmacol. 2016;194:260-8.

42. Semwal RB, Semwal DK, Combrinck S, Viljoen AM. Gingerols and shogaols: Important nutraceutical principles from ginger. Phytochemistry. 2015;117:55468.

43. Li Y, Tran VH, Duke CC, Roufogalis BD. Preventive and protective properties of Zingiber officinale (ginger) in diabetes mellitus, diabetic complications, and associated lipid and other metabolic disorders: A brief review. Evid Based Complement Alternat Med. 2012;516870.

44. Mahluji S, Attari VE, Mobasseri M, Payahoo L, Ostadrahimi A, Golzari SE. Effects of ginger (Zingiber officinale) on plasma glucose level, hba1c and insulin sensitivity in type 2 diabetic patients. Int J Food Sci Nutr. 2013;64(6):682-6.

45. Mozaffari-Khosravi H, Talaei B, Jalali BA, Najarzadeh A, Mozayan MR. The effect of ginger powder supplementation on insulin resistance and glycemic indices in patients with type 2 diabetes: A randomized, double-blind, placebo-controlled trial. Complement Ther Med. 2014;22(1):9-16.

46. Arablou T, Aryaeian N, Valizadeh M, Sharifi F, Hosseini A, Djalali M. The effect of ginger consumption on glycemic status, lipid profile and some inflammatory markers in patients with type 2 diabetes mellitus. Int J Food Sci Nutr. 2014;65(4):515-20.

47. Arıtuluk ZC, Ezer N. Halk arasında diyabete karşı kullanılan bitkiler (Türkiye)-II. Hacettepe Üniversitesi Eczacılık Fakültesi Dergisi 2012;32(2):179-208.

48. Kianbakht S, Khalighi-Sigaroodi F, Dabaghian FH. Improved glycemic control in patients with advanced type 2 diabetes mellitus taking Urtica dioica leaf extract: A randomized double-blind placebo-controlled clinical trial. Clin Lab. 2013;59(9-10):1071-6.

49. Namazi N, Tarighat A, Bahrami A. The effect of hydro alcoholic nettle (Urtica dioica) extract on oxidative stress in patients with type 2 diabetes: A randomized double-blind clinical trial. Pak J Biol Sci. 2012;15(2):98102.

50. Bailey CJ, Day C. Metformin: Its botanical background. Practical Diabetes Int. 2004;21(3):115-7. 